\title{
Baroreflex function in a patient with Bartter's syndrome
}

There is little information regarding circulatory responses in Bartter's syndrome, with the exception of marked resistance to vasopressors. We investigated baroreflex function in a 40-year-old woman with this syndrome. The patient showed oscillation of heart rate even with a small increase in blood pressure after administration of vasopressor agents. Variations in heart rate and blood pressure were exaggerated during halothane, nitrous oxide and oxygen anaesthesia. Although the mechanism of the unstable baroreflex in this syndrome remains to be proved, the instability may be atributable to many factors such as prostaglandins, hypovolemia, hypokalemia, halothane, nitrous oxide and positive pressure ventilation.

Bartter's syndrome is rare, although the exact incidence is not known. ${ }^{1}$ The syndrome is characterized by hypokalemic hypochloremic alkalosis, hyperreninemia, hyperaldosteronism and hyperplasia of the juxtaglomerular apparatus of the kidneys. Patients with this syndrome have normal blood pressure and show marked resistance to the pressor actions of angiotension II and norepinephrine. ${ }^{1-7}$ Because treatment with prostaglandin synthetase

\section{Key words}

COMPLICATIONS: Bartter's syndrome; HORMONE: prostaglandins; REFLEX: baroreflex; SYMPATHETIC NERYOUS SYSTEM: sympathomimetic agents.

From the Department of Anesthesiology, Sapporo Medical College and Hospital, Chuoku, Sapporo, Hokkaido and the Department of Anesthesiology, Institute of Clinical Medicine, University of Tsukuba, Sakuramura, Ibaraki, Japan.

Address correspondence to: Dr. Nishikawa, Department of Anesthesiology, Sapporo Medical College and Hospital, South-1, West-16, Chuoku, Sapporo, Hokkaido 060 Japan. inhibitor tends to correct many of the abnormalities of the syndrome, a primary physiologic defect in Bartter's syndrome has been suggested to be an over production of prostaglandins, causing vascular insensitivity to vasopressors, ${ }^{1-4,6,7}$ and enhanced vagus-mediated depressor effects. ${ }^{8}$ However, baroreflex functions in this syndrome has never been investigated in a patient awake or during anaesthesia. We report studies of the baroreflex function in a patient with Bartter's syndrome.

\section{Case report}

A 40 -year-old woman, weighing $39.5 \mathrm{~kg}$, with a clinical diagnosis of Bartter's syndrome, was scheduled for a renal biopsy, for definitive diagnosis. On admission, blood pressure was $90 / 60 \mathrm{mmHg}$, heart rate 80 beats $\min ^{-1}$. The chest roentgenogram revealed a small heart (cardiothoracic ratio 32 per cent). An electrocardiogram revealed no abnormality except prolongation of the PR interval $(0.22 \mathrm{sec})$. The patient was extremely resistant to vasopressors; a pressor test with angiotensin II and norepinephrine at doses of 0.015 and $0.3 \mu \mathrm{g} \cdot \mathrm{kg}^{-1}$. $\mathrm{min}^{-1}$ respectively produced only a $10 \mathrm{mmHg}$ rise of mean blood pressure. The normal response is more than $35 \mathrm{mmHg}$ and $25 \mathrm{mmHg}$, respectively. Biochemical examinations demonstrated hypokalemia $\left(3.1 \mathrm{mEq} \cdot \mathrm{L}^{-1}\right)$, hypochloremia $(89$ $\left.\mathrm{mEq} \cdot \mathrm{L}^{-1}\right)$, normal serum sodium $\left(133 \mathrm{mEq} \cdot \mathrm{L}^{-1}\right)$ and serum calcium $\left(4.8 \mathrm{mEq} \cdot \mathrm{L}^{-1}\right)$. Blood urea nitrogen and serum creatinine were $21 \mathrm{mg} \cdot \mathrm{dl}^{-1}$ and $1.2 \mathrm{mg} \cdot \mathrm{dl}^{-1}$, respectively. The $\mathrm{pHa}$ was 7.55 , $\mathrm{PaCO}_{2} 40 \mathrm{mmHg}, \mathrm{PaO}_{2} 91 \mathrm{mmHg}$, and base excess $10.6 \mathrm{mEq} \cdot \mathrm{L}^{-1}$. Endocrine studies revealed increased plasma renin activity of $41.9 \mathrm{ng} \cdot \mathrm{ml}^{-1} \cdot \mathrm{h}^{-1}$ and a plasma aldosterone level of $195.5 \mathrm{pg} \cdot \mathrm{ml}^{-1}$ (normal range $1-2.5 \mathrm{ng} \cdot \mathrm{ml}^{-1} \cdot \mathrm{h}^{-1}$ and $10-50 \mathrm{pg}$. $\mathrm{ml}^{-1}$, respectively). Preoperative medications consisted of a potassium supplement, $200 \mathrm{mEq} \cdot \mathrm{day}^{-1}$, and indomethacin $75 \mathrm{mg} \cdot$ day $^{-1}$.

Informed consent was obtained from the patient. 


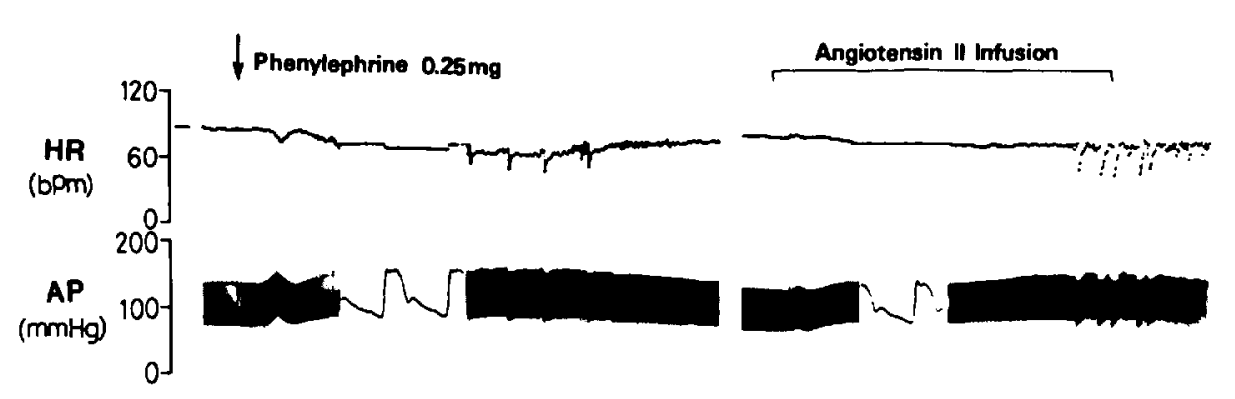

Awake

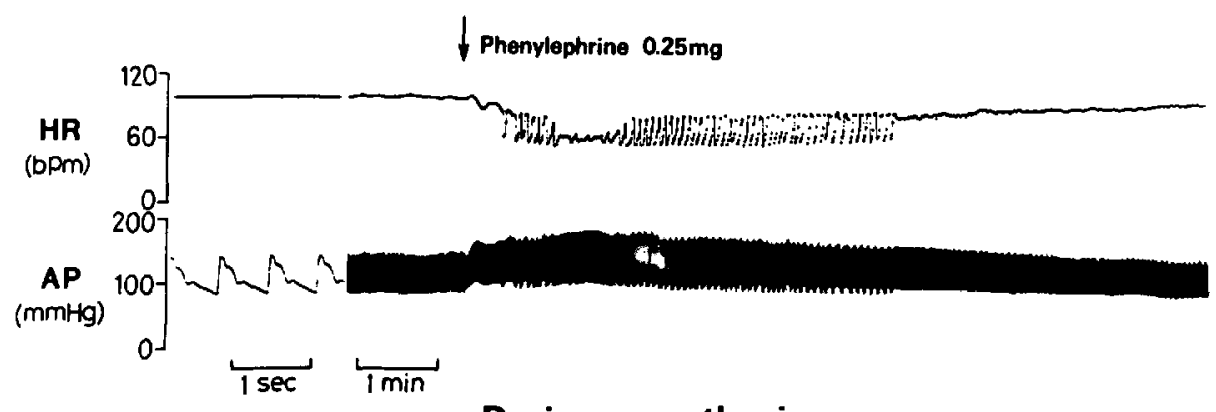

During anesthesia

FIGURE Polygraph tracings of heart rate (HR) and arterial blood pressure (AP). Upper left panel: Note the repetition of bradycardia with the increases of blood pressure after phenylephrine $0.25 \mathrm{mg}$ IV. Upper right panel: Angiotensin II produced the same phenomenon as pictured in the left panel. Lower panel: Note the considerably unstable heart rate and blood pressure after phenylephrine $0.25 \mathrm{mg}$ IV during halothane, nitrous oxide, and oxygen anaesthesia. For further discussion, see the text.

On the operative day, hydroxyzine $100 \mathrm{mg}$ and meperidine $35 \mathrm{mg}$ were administered I.M. one hour before arrival in the operating room. A 16-gauge intravenous cannula was placed for infusion of lactated Ringer's solution and a 19-gauge cannula was placed in the left radial artery to permit continuous blood pressure monitoring and blood sampling. The latter was connected to a Statham P23ID transducer (Gould, USA); the signal was amplified and recorded on six-channel polygraph recorder (Polygraph 146 and Rectigraph-8H, Sanei Instrument, Tokyo). Baroreflex control of heart rate was assessed quantitatively by a pressor test as described in the literature. ${ }^{9,10}$ Beat to beat systolic blood pressure ( $\mathrm{mmHg}$ ) and $\mathrm{R}-\mathrm{R}$ interval (msec), obtained from simultaneous recording of direct arterial blood pressure and heart rate, were linearly related over the first period of blood pressure increase. The slope of this relationship was calculated in msec of $\mathrm{R}-\mathrm{R}$ interval change per $\mathrm{mmHg}$ increase in systolic blood pressure, and this was defined as the baroreflex sensitivity.

The baseline blood pressure was $135 / 70 \mathrm{mmHg}$ and heart rate 87 beats $\cdot \min ^{-1}$. When phenylephrine, $0.25 \mathrm{mg}$, was rapidly injected intravenously, the blood pressure increased to $155 / 90 \mathrm{mmHg}$ transiently, then rose slowly to $160 / 90$, while the heart rate decreased to 72 beats $\cdot \mathrm{min}^{-1}$ transiently, thereafter varying remarkably (from 48 to 72 beats $\cdot \min ^{-1}$ ). During this period, the increase in systolic blood pressure was small $(25 \mathrm{mmHg})$, and the heart rate was extremely labile, but no arrhythmia appeared (Figure, upper left panel). The baroreflex sensitivity was $7.1 \mathrm{msec} \cdot \mathrm{mmHg}^{-1}$ (Table). A 
TABLE Results of pressor test

\begin{tabular}{llllll}
\hline & & & $\begin{array}{l}\text { Systolic } \\
\text { blood } \\
\text { pressure } \\
(\mathrm{mmHg})\end{array}$ & $\begin{array}{l}\text { R-R } \\
\text { interval } \\
(\mathrm{msec})\end{array}$ & $\begin{array}{l}\text { Barorefiex } \\
\text { sensitivity } \\
\left(\mathrm{msec} \cdot \mathrm{mmHg}^{-1}\right)\end{array}$ \\
\hline Awake & Phenylephrine & Pre & 135 & 690 & 7.1 \\
& $0.25 \mathrm{mg}$ & Post & 155 & 833 & \\
& Angiotensin II & Pre & 135 & 714 & 4.3 \\
& $0.1 \mu \mathrm{kg}^{-1} \cdot \mathrm{min}^{-1}$ & Post & 155 & 800 & \\
$\begin{array}{l}\text { Halothane/ } \\
\text { nitrous oxide } \\
\text { anaesthesia }\end{array}$ & Phenylephrine & Pre & 140 & 625 & 3.5 \\
\hline
\end{tabular}

pressor test with angiotensin II was performed after the blood pressure and heart rate had returned to baseline levels. Angiotensin II was infused intravenously at the rate of $0.1 \mu \mathrm{g} \cdot \mathrm{kg}^{-1} \cdot \mathrm{min}^{-1}$. Systolic blood pressure increased about $25 \mathrm{mmHg}$, while the heart rate was unstable, decreasing intermittently from 75 to 50 beats $\cdot \min ^{-1}$; the oscillation of heart rate was observed periodically several times per minute (Figure, upper right panel). The baroreflex sensitivity was $4.3 \mathrm{msec} \cdot \mathrm{mmHg}^{-1}$.

Thereafter, general anaesthesia was induced with thiamylal $200 \mathrm{mg}$ given slowly and the trachea was intubated after intravenous succinylcholine $50 \mathrm{mg}$. The blood pressure decreased from $130 / 75$ to $95 / 55 \mathrm{mmHg}$ and heart rate increased from 81 to 87 beats $\min ^{-1}$ after thiamylal administration, then changed to $145 / 90 \mathrm{mmHg}$ and 84 beats $\cdot \mathrm{min}^{-1}$, respectively during laryngoscopy and endotracheal intubation. During this period the heart rate was relatively stable. Anaesthesia was maintained with halothane ( 0.5 to 1.0 per cent inspired) in nitrous oxide and oxygen ( 3 and $2 \mathrm{~L} \cdot \mathrm{min}^{-1}$, respectively). Ventilation was controlled with the use of intravenous pancuronium $3 \mathrm{mg}$, maintaining $\mathrm{PaCO}_{2}$ at about $35 \mathrm{mmHg}$.

The pressor test with phenylephrine was repeated 30 minutes later during a period of stable blood pressure and heart rate. Blood pressure rose transiently from $140 / 85$ to $165 / 100$, then increased slowly to $180 / 100 \mathrm{mmHg}$ after phenylephrine 0.25 mg. Heart rate initially decreased from 96 to 84 beats $\mathrm{min}^{-1}$, then varied considerably from 51 to 81 beats $\min ^{-1}$. The cycles of the oscillation of heart rate observed during halothane, nitrous oxide, and oxygen anaesthesia was about $12-13$ per minute. A small oscillation of blood pressure (around
$15 \mathrm{mmHg}$ ) was also observed; this being consistent with that of heart rate (Figure, lower panel). The baroreflex sensitivity was $3.5 \mathrm{msec} \cdot \mathrm{mmHg}^{-1}$ (Table). The remaining anaesthetic course was uneventful. Microscopic examination revealed juxtaglomerular hyperplasia of the kidney.

\section{Discussion}

The baroreflex is one of the most important neuronal control systems for short-term regulation of blood pressure. "I This patient's baroreflex control of heart rate was extremely unstable and the vasopressors induced a remarkable oscillation of heart rate, even with a small increase in blood pressure, and these oscillations were aggravated in the presence of halothane, nitrous oxide and oxygen.

Although the mechanism of the unstable baroreflex control system remains to be proved, it is evident that vagus-mediated bradycardia is notable even with a very small increase of blood pressure. The sensitivity of the baroreflex was 7.1 and $4.3 \mathrm{msec} \cdot \mathrm{mmHg}^{-1}$ before anaesthesia, and 3.5 $\mathrm{msec} \cdot \mathrm{mmHg}^{-1}$ during anaesthesia. These values in the unanaesthetized state and during anaesthesia are comparable to those reported previously..$^{9,10,12}$ Presumably, the unstable baroreflex in this patient may be explained due to an impaired resetting of the baroreceptors, or a defect of central modulation of the reflex.

A cardinal feature of Bartter's syndrome is overproduction of prostaglandins such as $\mathrm{PGD}_{2}$, $\mathrm{PGE}_{2}$, and $\mathrm{PGI}_{2}{ }^{1-4,6,7}$ There have been reports that pressor actions of sympathomimetics are counteracted by prostaglandins in this syndrome. ${ }^{1-4.6,7}$ Staszewska-Barczak ${ }^{8}$ demonstrated that the hypo- 
tensive and bradycardia responses to nicotine were potentiated by intracoronary or intravenous infusion of $\mathrm{PGI}_{2}$ and $\mathrm{PGD}_{2}$ while the pressor effects evoked by bradykinin were potentiated by intracoronary infusion of $\mathrm{PGE}_{2}$, and that indomethacin reduced this pressor effect. He also observed that $\mathrm{PGE}_{2}$ had no effect on the nicotine-induced depressor effect, while $\mathrm{PGI}_{2}$ reduced sympatheticallymediated reflex effects of bradykinin. In addition, because it has been reported that $\mathrm{PGI}_{2}$ (not $\mathrm{PGE}_{2}$ ) is a predominant active metabolite of arachidonic acid in blood vessels, it would be possible that $\mathrm{PGI}_{2}$ plays a more important role in circulatory disturbances in this syndrome. Patients with Bartter's syndrome therefore seem to be in vagal dominant state, although preoperative indomethacin treatment might modify the effects of the prostaglandins. ${ }^{8,13}$ The minimal change in heart rate, even with significant increases in blood pressure observed during laryngoscopy and tracheal intubation, support this speculation. Sympathomimetic responses such as tachycardia and hypertension usually occur during these procedures.

Normally, the heart rate responses to stimulation of the vagus nerve occur very rapidly, but sympathetic responses occur slowly. ${ }^{11}$ In the resting condition, the increase of heart rate by complete vagolysis is much larger than the decrease produced by complete sympathetic blockade. ${ }^{14}$ In Bartter's syndrome sympathetic tone is already decreased and sympathetic activities are not able to counteract the increased vagal tone, thus resulting in marked bradycardia. Because of impaired sympathetic responses in Bartter's syndrome, a depressor test may be more relevant, rather than a pressor test as in our patient. However, the remarkable oscillation of heart rate observed in our patient cannot be explained only on the basis of an imbalance in the autonomic nervous system. Hypovolemia, which can be present in Bartter's syndrome ${ }^{15}$ may be also responsible for an unstable baroreflex, since the cardiovascular control system, including the baroreceptor response, oscillates considerably in hypovolemia. $^{16}$ In addition, hypokalemia, which is another feature of Bartter's syndrome, ${ }^{1-6}$ may also be responsible for unstable baroreceptor responses, since hypokalemia has been reported to increase the pressure threshold at which baroreceptor discharges are initiated. ${ }^{17,18}$

In the presence of halothane, nitrous oxide, oxygen and pancuronium, the oscillation of heart rates induced by phenylephrine was obviously accentuated in this particular patient, though halothane and nitrous oxide have been reported to attenuate the baroreflex responses. ${ }^{9,10,19-21}$ The reason for this is unclear. Phenylephrine per se may have an enhancing effect on the baroreflex responses, ${ }^{22}$ and positive pressure ventilation could modify the baroreflex control of heart rate. ${ }^{23}$ And it is possible that inhalation anaesthetics, such as halothane, could depress the sympathetic nervous system, intensifying the vagal dominant state produced by prostaglandins.

In summary, unstable baroreceptor responses exist in patients with Bartter's syndrome; this instability of the reflex responses may be attributable to many factors, including prostaglandins, hypovolemia, hypokalemia and positive pressure ventilation. Further the presence of halothane and nitrous oxide may aggravate the instability.

\section{References}

1 Abston PA, Priano LL. Bartter's syndrome: Anesthetic implications based on pathophysiology and treatment. Anesth Analg 1981; 60: 764-6.

2 Radfar N, Gill JR Jr, Bartter FC, Bravo E, Taylor $A A, B o w d e n$ RE. Hypokalemia, in Bartter's syndrome and other disorders, produces resistance to vasopressors via prostaglandin overproduction Proc Soc Exp Biol Med 1978; 158: 502-7.

3 Barttet FC. Bartter's syndrome. Urol Clin North Am 1977; 4: 253-61.

4 Donker AJM, deJong PE, Statius van Eps $L W$, Brentjens JRH, Bakker $K$, Doorenbos $H$. Indomethacin in Bartter's syndrome. Nephron 1977; 19: 200-13.

5 Barter FC, Pronove P, Gill JR Jr, MacCardle RC. Hyperplasia of the juxtaglomerular complex with hyperaldosteronism and hypokalemic alkalosis. A new syndrome. Am J Med 1962; 33: 811-28.

6 Horton $R$, Zipser $R$, Fichman $M$. Prostaglandins, renal function and vascular regulation. Med Clin North Am 1981; 65: 891-914.

7 Sasaki $H$, Okumura $M$, Asano $T$, Arakawa $K$. Responses to angiotensin II antagonist before and after treatment with indomethacin in Bartter's syndrome. Br Med J 1977; 2: 995-6.

8 Staszewska-BarczakJ. Prostanoids and cardiac reflexes of sympathetic and vagal origin. Am J Cardiol $1983 ; 52$ : 36A-4SA. 
9 Duke PC, Fownes D, Wade JG. Halothane depresses baroreflex control of heart rate in man. Anesthesiology 1977 ; 46: 184-7.

10 Duke $P C$, Trosky $S$. The effect of halothane with nitrous oxide on baroreflex control of heart rate in man. Can Anaesth Soc J 1980; 27: 531-4.

11 Scher $A M$. Carotid and aortic regulation of arterial blood pressure. Circulation 1977; 56: 521-8.

12 Smyth HS, Sleight $P$, Pickering $G W$. Reflex regulation of arterial pressure during sleep in man: a quantitative method of assessing baroreflex sensitivity. Circ Res 1969; 24: 109-21.

13 Ismailov ShI, Valdman AV. Hemodynamic responses of normotensive and hypertensive rats to administration of prostaglandins and indomethacin. Biullenten' Eksperimental' noi Biologii i Meditsiny $1982 ; 94: 45-8$.

14 Robinson BF, Epstein SE, Beiser GD, Braunwald $E$. Control of heart rate by the autonomic nervous system. Circ Res 1966; 19: 400-11.

15 Modlinger RS, Nicolis GL, Krakoff LR, Gabrilove $J L$. Some observations on the pathogenesis of Bartter's syndrome. N Engl J Med 1973; 289: 1022-4.

16 Guyton $A C$. Textbook of medical physiology, 5th ed. Philadelphia: Saunders, 1976; 11.

17 Andresen $M C$, Kuraoka $S$, Brown $A M$. Individual and combined actions of calcium, sodium, and potassium ions on baroreceptors in the rat. Circ Res 1979; 45: 757-63.

18 Saum WR, Ayachi S, Brown AM. Actions of sodium and potassium ions on baroreceptors of normotensive and spontaneously hypertensive rats. Circ Res 1977; 41: 768-74.

19 Seagard JL, Hopp FA, Bosnjak ZJ. Elegbe EO, Kampine $J P$. Extent and mechanism of halothane sensitization of the carotid sinus baroreceptors. Anesthesiology 1983; 58: 432-7.

20 Seagard $J$, Hopp FA, Donegan JH, Kalbfleisch $J H$, Kampine $J P$. Halothane and the carotid sinus reflex: Evidence for multiple sites of action. Anesthesiology 1982; 57: 191-202.

21 Bagshaw RJ, Cox RH. Nitrous oxide and the baroreceptor reflexes in the dog. Acta Anaesthesiol Scand 1982; 26: 31-8.

22 Peveler RC, Bergel DH, Robinson JL, Sleight $P$. The effect of phenylephrine upon arterial pressure, carotid sinus radius and baroreflex sensitivity in the conscious greyhound. Clin Sci 1983; 64: 455-61.
23 Davis AL, McCloskey DI, Potter EK. Respiratory modulation of baroreceptor and chemoreceptor reflexes affecting heart rate through the sympathetic nervous system. J Physiol 1977; 272: 691-703.

\section{Résumé}

Il y a très peu d'information concernant les réponses vasculaires chez les patients atteints de syndrome de Bartier à l'exception de celle concernant une résistance marquée aux vasopresseurs. On a investigué la fonction des barorécepteurs chez une femme âgée de 40 ans atteinte de ce syndrome. La patiente a démontré une oscillation de la fréquence cardiaque même avec une augmentation minime de la tension artérielle suite à l'administration d'agents vasopresseurs. Les variations de la fréquence cardiaque et de la pression artérielle étaient exagérées lors de l'anesthésie d̀ l'halothane, protoxide d'azote et oxygène. Même si le mécanisme de cette instabilité des barorécepteurs dans ce syndrome reste à prouver, cette instabilité peut-être attribuer d plusieurs facteurs dont les prostaglandines, l'hypovolémie, I'hypokalémie, l'halothane, le protoxide d'azote et la ventilation à pression positive. 